\title{
Contribution of primary aerosol emissions from vegetation-derived sources to fine particle concentrations in Los Angeles
}

\author{
Lynn M. Hildemann, ${ }^{1}$ Wolfgang F. Rogge, ${ }^{2,3}$ Glen R. Cass, ${ }^{2}$ \\ Monica A. Mazurek, ${ }^{4,5}$ and Bernd R. T. Simoneit ${ }^{6}$
}

\begin{abstract}
Field measurements of the $n$-alkanes present in fine atmospheric aerosols show a predominance of odd carbon numbered higher molecular weight homologues $\left(\mathrm{C}_{27}-\mathrm{C}_{33}\right)$ that is characteristic of plant waxes. Utilizing a local leaf wax $n$-alkane profile in conjunction with an air quality model, it is estimated that, at most, $0.2-1.0 \mu \mathrm{g} \mathrm{m}^{-3}$ of the airborne fine particulate matter $\left(d_{p}<2.1 \mu \mathrm{m}\right)$ present in the Los Angeles basin could originate from urban vegetative detritus; this corresponds to approximately $1-3 \%$ of the total ambient fine aerosol burden. However, some of the observed vegetation aerosol fingerprint in the Los Angeles air may be due in part to emissions from food cooking rather than plant detritus. Seasonal trends in the ambient $n$-alkane patterns are examined to seek further insight into the relative importance of anthropogenic versus natural sources of vegetation-derived fine particulate matter.
\end{abstract}

\section{Introduction}

Analysis of airborne organic particulate matter samples from a variety of urban, rural, and remote locations has consistently revealed a distinctive $n$ alkane distribution that is characteristic of plant waxes [Simoneit, 1979, 1989; Simoneit and Mazurek, 1981, 1982; Cox et al., 1982; Gagosian et al., 1982; Wils et al., 1982; Mazurek and Simoneit, 1984; Doskey and Andren, 1986; Simoneit et al., 1988, 1990, 1991a,b; Mazurek et al., 1989; Sicre et al., 1990; Rogge et al., 1993a,c]. This distribution, which shows a predominance of odd carbon numbered n-alkanes between $\mathrm{C}_{27}$ and $\mathrm{C}_{33}$, has led to speculation that primary aerosol emissions from vegetation may constitute a significant source of ambient aerosol.

Only a few attempts have been made to quantify the extent to which primary aerosol emissions from plant detritus may contribute to ambient particulate concentration levels. For a remote desert location in the southwestern United States, Mazurek et al. [1991] estimated that plant waxes comprise $8-38 \%$ of the total

\footnotetext{
${ }^{1}$ Department of Civil Engineering, Stanford University, Stanford, California.

${ }^{2}$ Department of Environmental Engineering Science, California Institute of Technology, Pasadena.

${ }^{3}$ Now at Department of Civil and Environmental Engineering, Florida International University, Miami.

${ }^{4}$ Environmental Chemistry Division, Brookhaven National Laboratory, Upton, New York.

${ }^{5}$ Now at Institute of Marine and Coastal Sciences, Rutgers University, New Brunswick, New Jersey.

${ }^{6}$ College of Oceanic and Atmospheric Sciences, Oregon State University, Corvallis.
}

Copyright 1996 by the American Geophysical Union.

Paper number 95JD02136.

0148-0227/96/95JD-02136\$09.00 extractable organics in particulate matter having an aerodynamic diameter of $<15 \mu \mathrm{m}$. For Los Angeles aerosol, Simoneit [1986] estimated that $6-20 \%$ of the fine organic material in the air was vegetative in origin; however, this estimate included anthropogenic sources of plant-derived emissions (such as tobacco smoke and the plant material in resuspended road dust) in addition to primary source emissions of plant waxes from local vegetation.

Because these previously published studies utilize a single ratio (of odd-to-even carbon numbered $n$ alkanes) to apportion the lipids between plant waxes and petroleum emissions, they are best viewed as estimates. In the present paper, we utilize a transport model, in conjunction with source profiles and ambient measurements, to calculate an upperbound estimate of the concentration of fine (aerodynamic diameter $<2.1 \mu \mathrm{m}$ ) aerosol in the urban atmosphere of Los Angeles that could be attributed to primary emissions from vegetation. The approach taken is to first compute the higher molecular weight $n$-alkane concentrations in the southern California atmosphere that are due to inventoried anthropogenic emission sources. Then, the $n$-alkane pattern that remains as the residual difference between the input due to anthropogenic sources and the measured ambient $n$-alkane concentrations will allow an upper limit to be placed on the ambient concentration of fine aerosol in the Los Angeles atmosphere that could be due to vegetative detritus.

\section{Methods}

\section{Collection of Vegetative Detritus}

A published survey of the vegetation present in the Los Angeles basin in 1982 [Winer et al., 1983; Miller and Winer, 1984] was utilized to determine the predominant plant species present in this urban area. The 62 species selected for sampling, which are itemized elsewhere [Hildemann et al., 1991, Table IV], 
consisted of 51 species of urban vegetation (including broad leaf trees, conifers, palms, shrubs, grasses, and groundcover), 1 species of agricultural vegetation, and 10 species of natural vegetation. In the $4504 \mathrm{~km}^{2}$ area surveyed within the Los Angeles basin in 1982, urban vegetation covered $16 \%$ of the land, agricultural vegetation covered $2 \%$, and natural vegetation covered $29 \%$; the remaining acreage consisted of $43 \%$ urban barren land (e.g., covered by pavement or structures), $2 \%$ natural barren land, and $7 \%$ nonvegetated land [Winer et al., 1983; Miller and Winer, 1984]. On average, there were 218 metric tons of leaf mass per square kilometer of land: $43 \%$ consisting of urban vegetation, $53 \%$ natural vegetation, and the rest due to agricultural vegetation.

Separate samples of green leaves and dead leaves were collected from each of the 62 plant species over a 4-day period in early December 1988. To create composite samples of dead leaf and green leaf matter, these samples were combined so that the mass of leaves from each species contained in the composite was proportional to its contribution to the estimated leaf mass in the Los Angeles basin [Hildemann et al., 1991, Table IV]

Protusions of surface plant waxes can be dislodged under normal ambient weathering conditions [Simoneit, 1979; Kolattukudy, 1980; Simoneit and Mazurek, 1981. Rogge et al., 1993b]. To simulate a windblown generation process, each composite leaf sample was placed in a Teflon bag and mechanically agitated while passing purified air (treated via HEPA filtration and an activated carbon bed) through the bag. The air exiting the bag was drawn through cyclone separators, with the remaining fine particulate matter collected downstream on multiple filters in parallel.

The total mass of fine detritus collected was determined by gravimetric analysis of samples collected on Teflon filters. Samples destined for detailed organic analyses were collected on multiple quartz fiber filters (Pallflex $2500 \mathrm{QAO}$ ) that had been baked at $750^{\circ} \mathrm{C}$ for 2-4 hours to minimize the blank organic carbon levels.

\section{Organic Chemical Analyses of Source Samples}

Fine aerosol samples of green and dead leaf urban vegetative detritus were extracted and analyzed on the basis of the procedure developed by Mazurek et al. [1987]. For detailed descriptions, the reader is referred to previous publications le.g., Mazurek et al., 1987, 1993; Rogge et al., 1991, 1993b].

For the air quality model utilized in this study, $n$-alkane mass emission rates are needed for each source type (besides vegetation) that contributes particulate $n$-alkanes to the atmosphere. The sampling techniques utilized for these various source types have been described elsewhere [Hildemann et al., 1991], as have been the extraction and gas chromatography-mass spectroscopy (GC-MS) analysis procedures utilized [e.g., Rogge et al., 1991].

\section{Collection and Analysis of Ambient Samples}

To provide a comparison with the predictions made by the air quality model, $n$-alkane profiles for ambient atmospheric aerosol samples were needed. Such samples were collected once every 6 days for 24 hours over the entire calendar year 1982 by Gray et al. [1986]. Monthly composites of the ambient samples collected at Pasadena, downtown Los Angeles, and west Los Angeles were extracted and analyzed via
GC-MS in a manner analogous to the methods used for the source samples. Background organic compound concentrations present in marine air upwind of the study area were determined by analysis of samples collected in 1982 at San Nicolas Island. Further details regarding the extraction and analysis of the ambient samples have been published previously [Mazurek et al., 1987, 1993; Rogge et al., 1993c].

\section{Modeling Approach}

An air quality model developed by Cass $[1977,1981]$ and modified by Gray [1986] was used to determine what quantity of the ambient $n$-alkane concentrations is due to sources other than vegetative detritus. This model utilizes a Lagrangian particle-in-cell technique to compute the ambient concentrations of primary fine particulate matter components on the basis of primary source emissions. The geographical area modeled is an $80 \mathrm{~km} \times 80 \mathrm{~km}$ square grid containing 625 grid cells centered over downtown Los Angeles [see Hildemann et al., 1993, Figure 1]. Model inputs include background (upwind) pollutant concentration levels, emission strengths and locations for more than 40 different primary carbon particle source types in the Los Angeles area, hourly wind speeds and directions, and hourly mixing depths. This Lagrangian model only accounts for the transport of primary aerosol emissions; secondary aerosol concentrations are not computed. Because the high molecular weight $n$-alkanes studied here originate from primary particulate emissions, the model is well suited for the present case.

The model has previously been shown to work well for predicting monthly average concentrations of fine elemental carbon [Gray, 1986], indicating that the major sources of elemental carbon have been properly identified and the transport processes are well represented. Further details regarding the model structure and the major sources of fine organic aerosol inventoried can be found in the work by Hildemann et al. [1993].

\section{Results}

A characteristic predominance of odd carbon numbered over even carbon numbered higher molecular weight $n$-alkanes has been observed in ambient aerosols, both in remote and urban areas [Simoneit and Mazurek, 1981, 1982; Wils et al., 1982; Mazurek and Simoneit, 1984; Doskey and Andren, 1986; Simoneit et al., 1988, 1991a,b; Mazurek et al., 1989; Rogge et al., 1993c]. This $n$-alkane distribution has also been demonstrated to be a characteristic feature of plant waxes [e.g. Eglinton and Hamilton, 1963; Stránský et al., 1967; Simoneit and Mazurek, 1982; Mazurek and Simoneit, 1984; Rogge et al., 1993b]. The approach taken here is to utilize higher molecular weight $n$-alkane concentration patterns to deduce the quantity of plant wax derived higher molecular weight $n$-alkanes present in the atmosphere, from whence an upper limit can be placed on the mass of fine particle vegetative detritus in the atmosphere.

\section{Source Profiles}

The $n$-alkane profile measured [Rogge et al, 1993b] for the fine aerosol released from the Los Angeles green leaf composite is shown in Figure 1a. It consists of substantial amounts of the $\mathrm{C}_{29}, \mathrm{C}_{31}$, and $\mathrm{C}_{33} n$-alkanes, 

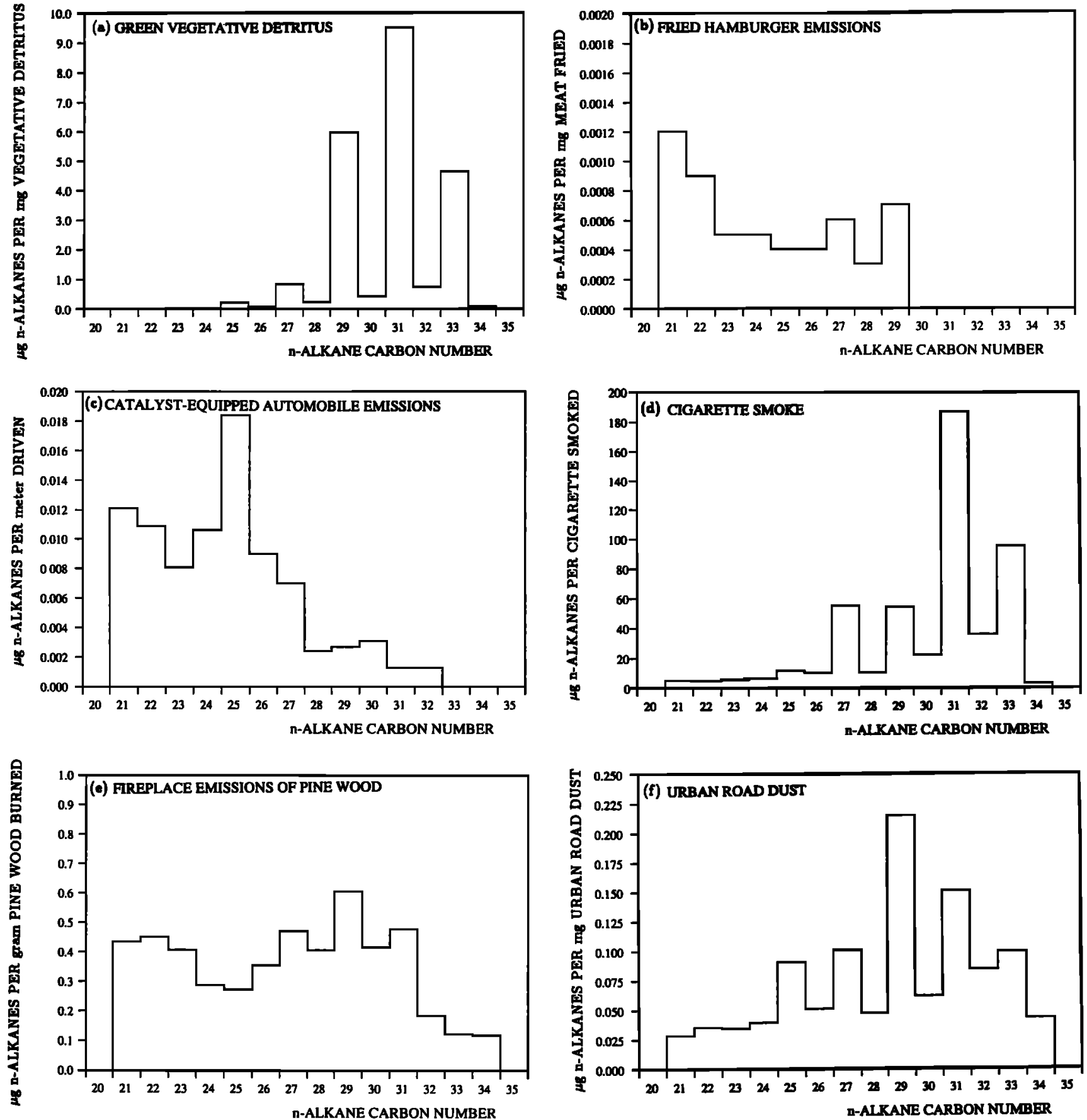

Figure 1. Examples of $n$-alkane profiles for emission sources used in the air quality modeling study: (a) green urban vegetative detritus; (b) fried hamburger emissions; (c) catalyst-equipped automobile emissions; (d) cigarette smoke; (e) fireplace combustion of pine wood; and (f) urban road dust.

with much smaller amounts of the other members of this homologous series; the dead leaf composite $n$-alkane distribution was quite similar [Rogge et al., 1993b]. To focus on the part of the $n$-alkane distribution expected to be most significantly affected by vegetation-derived inputs, only the $n$-alkanes between $\mathrm{C}_{27}$ and $\mathrm{C}_{34}$ are considered in subsequent calculations.

Examples of the $n$-alkane distributions measured for some of the major inventoried sources of high molecular weight $n$-alkane emissions in southern California also are shown in Figure 1. Two of the other sources in particular that might be expected to contribute at least partially to the ambient $n$-alkane profile observed for $\mathrm{C}_{27}$ through $\mathrm{C}_{34}$ include cigarette smoke and urban paved road dust. As shown in Figures $1 \mathrm{e}$ and 1f, both cigarette smoke and urban road dust exhibit a noticeable odd-to-even carbon number predominance. For cigarette smoke, this feature is due to the volatilization of tobacco leaf waxes during smoking [Rogge et al., 1994], while for urban road dust, it is due to the 


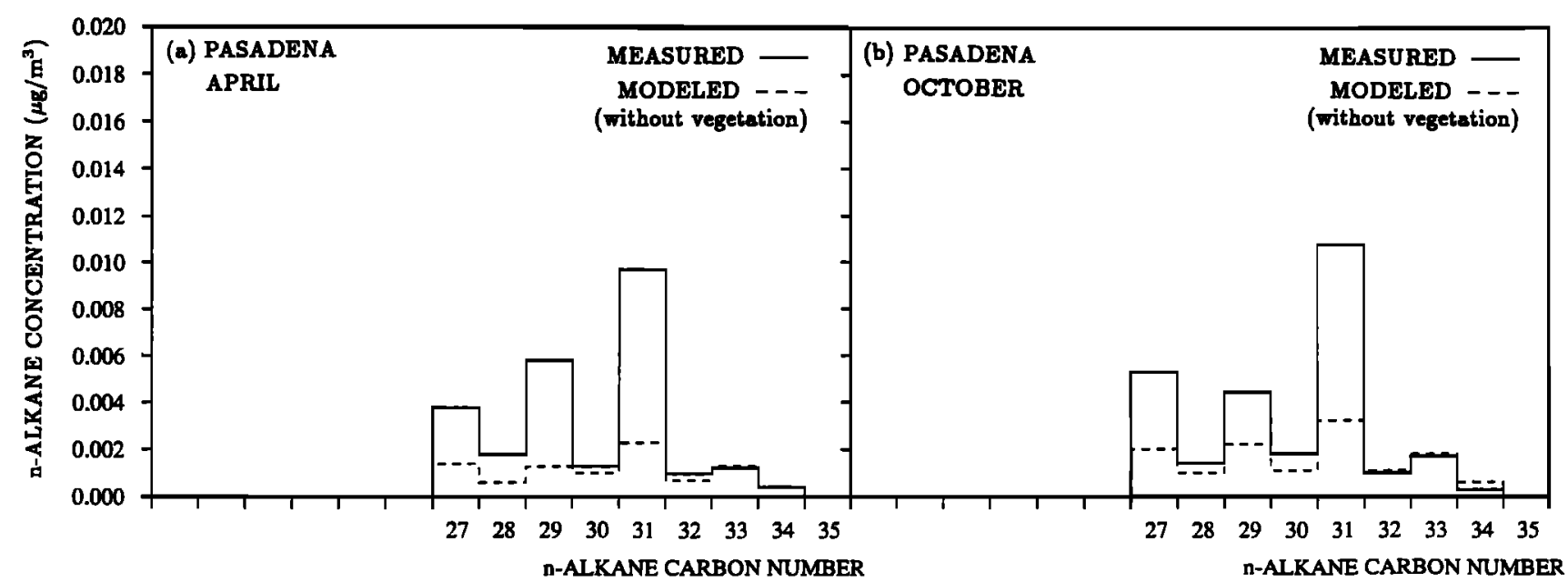

Figure 2. Comparison of modeled $n$-alkane concentrations due to the inventoried anthropogenic sources (such as those shown in Figures $1 \mathrm{~b}-1 \mathrm{f}$ ) versus ambient $n$-alkane concentrations measured in 1982: (a) Pasadena in April, and (b) Pasadena in October. Contributions from vegetative detritus are not included in these model predictions.

presence of pulverized vegetation as a component of the resuspended fine aerosol [Rogge et al., 1993a]. Thus the contributions of other sources to the ambient $n$-alkane concentrations must be calculated before the remainder can be attributed to uninventoried sources derived from vegetation.

\section{Model Predictions}

When the higher molecular weight $n$-alkane emission rates from all major inventoried emission sources of organic aerosol in Los Angeles are supplied to the air quality model, the ambient $n$-alkane concentration distribution in the atmosphere due to inventoried anthropogenic sources can be predicted. As illustrated in Figure 2, relatively close agreement is obtained between modeled and measured concentrations for the even carbon numbered $n$-alkanes. This indicates that (1) the major sources of the even carbon numbered $n$-alkanes have been accurately represented in the model, and (2) the bulk of the ambient even carbon numbered $n$-alkane concentrations can be attributed to inventoried primary source emissions. However, only a small portion of the observed odd carbon numbered $n$-alkanes between $\mathrm{C}_{27}$ and $\mathrm{C}_{34}$ can be attributed to inventoried anthropogenic sources, regardless of the site or the time of year.

The added mass of fine particulate vegetative detritus needed to give an optimal match between the modeled and measured concentrations was separately calculated for the $\mathrm{C}_{29} n$-alkane and the $\mathrm{C}_{31} n$-alkane, and then the two results were averaged. Because it is being assumed at this point that plant detritus is the only missing source of $n$-alkanes, this approach will give an upperbound estimate for the concentration of urban fine aerosol originating from vegetation.

As shown in Figure 3 , at most, $0.2-1.0 \mu \mathrm{g} \mathrm{m}^{-3}$ of fine particulate matter in the Los Angeles area atmosphere can be attributed to vegetative detritus. Substantial site-to-site and month-to-month variations are seen, but no overall trends are evident. In Pasadena, these upperbound predictions correspond to $0.8-3.1 \%$ (average $=1.6 \pm 0.8 \%$ ) of the total average monthly fine particulate matter concentrations; in downtown Los
Angeles, they represent $0.9-3.7 \%$ of the total (average $=2.3 \pm 0.7 \%$ ); and in west Los Angeles, they are $1.0-4.8 \%$ of the total (average $=2.5 \pm 1.1 \%$ ). Thus for the three sites considered, plant detritus, at most, constitutes $\sim 1-3 \%$ of the total ambient fine particulate matter.

These data can be used, in conjunction with the transport model, to approximate an upper bound on the mass of fine particulate matter released per day from vegetation within the $80 \mathrm{~km} \times 80 \mathrm{~km}$ Los Angeles study area. The Lagrangian transport model used determines, for a given spatial distribution of emissions from a particular source type, the atmospheric concentration increment that results at a given receptor air monitoring site within the modeling area. Each of these source-to-receptor transfer coefficients (in $\left(\mu \mathrm{g} \mathrm{m}^{-3}\right)$ per (ton $\mathrm{d}^{-1}$ ) emitted), when multiplied by an emission rate from the source type of interest (tons per day), yields

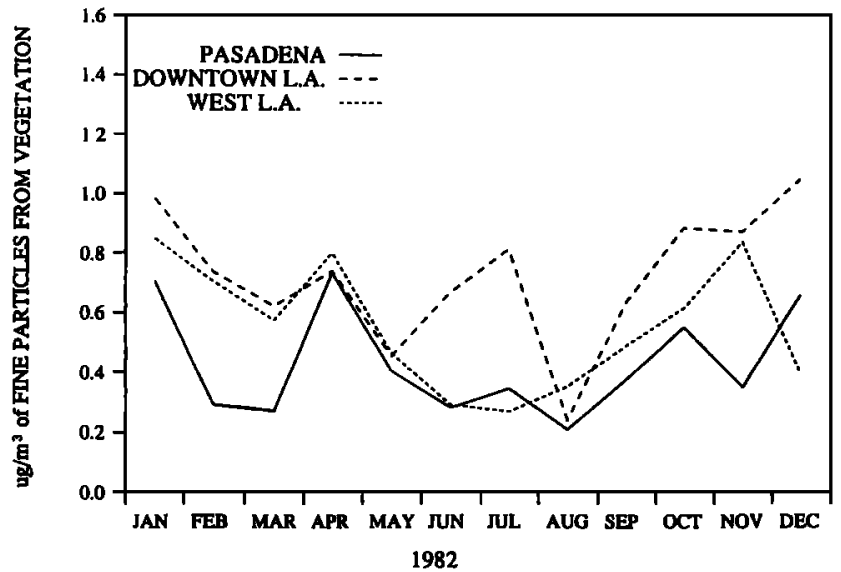

Figure 3. Upperbound estimates of the monthly average concentrations of ambient particulate matter attributable to urban vegetative detritus for Pasadena, west Los Angeles, and downtown Los Angeles. Values are calculated using the $\mathrm{C}_{29}$ and $\mathrm{C}_{31} n$-alkanes as tracers for vegetative detritus. 
the site-specific ambient concentration increment due to that source type.

If the ambient concentration increment from a source type and the transfer coefficient appropriate to the source's spatial distribution were known, then the mass of particulate matter emitted could be conversely calculated. However, to make such an estimate for vegetative detritus, the spatial distribution of plants in the Los Angeles area must be assumed to be similar to the distribution of another emission source for which source-to-receptor transport patterns have already been established by the model.

Because a much higher density of cultivated vegetation typically is found in residential neighborhoods in Los Angeles than in industrial and business districts, the spatial distribution of emissions from residences was chosen to approximate the spatial distribution of vegetation for this first effort at obtaining an emissions estimate. Fireplaces, a residential emission source type, are distributed spatially within the model in proportion to residential population density, so the transfer coefficients generated by the model for transport from fireplaces can be used to estimate transport from vegetated neighborhoods. It should be noted that this assumed spatial distribution for the vegetation does not properly reflect the growth of the natural vegetation on unpopulated hillsides; nonetheless, it provides a reasonable first approximation of the local mass emission rate due to vegetative detritus.

Using this approach, the upperbound estimate of fine particulate emissions from plants in the $80 \mathrm{~km} \times 80 \mathrm{~km}$ Los Angeles study area evaluated by the model is found to range between 1300 and $4000 \mathrm{~kg} \mathrm{~d}^{-1}$, depending on the month of the year. This corresponds to roughly 300-900 $\mathrm{g}$ of fine particulate matter emitted from urban vegetation per day per square kilometer of land within the heavily urbanized area modeled (the $4500 \mathrm{~km}^{2}$ of the modeling area which is land encompasses almost the same geographic region as what was surveyed for vegetation; the other $1900 \mathrm{~km}^{2}$ of the modeling area is ocean). In terms of the mass of vegetation present within the $80 \mathrm{~km} \times 80 \mathrm{~km}$ Los Angeles study area, this corresponds to $1.3-4.1 \mathrm{~g}$ of urban fine vegetative detritus emitted per day per metric ton of leaf mass.

It should be reemphasized that these numbers are rough estimates at best, in addition to representing upper bounds; however, they are the only such emissions estimates available to date to the best of our knowledge. Since the leaves sampled here were gathered in an urban area, the particulate matter released when leaf surfaces are agitated includes the resuspension of some urban particle dry deposits that exist on the leaf surfaces [Hildemann et al., 1991; Rogge et al., 1993b], so the particulate matter emission rates estimated here are higher than would be expected for vegetative detritus emissions generated in similar but less polluted areas.

\section{Discussion}

\section{Comparison of Model Predictions With Measurements}

Revised model estimates are shown in Figure 4, with the material estimated to be due to vegetative detritus appearing as shaded areas. It is seen that addition of suitable amounts of the green leaf detritus allows close agreement to be simultaneously obtained for the $\mathrm{C}_{29}$ and $\mathrm{C}_{31} n$-alkanes. However, in general the model, even when revised to include the urban vegetative detritus, underpredicts the $\mathrm{C}_{27} n$-alkane concentration, while it overpredicts the ambient levels of the $\mathrm{C}_{33} n$-alkane. Several hypotheses merit consideration to explain these differences.

First, it is possible that the relative proportions of the odd carbon numbered $n$-alkanes in the composited sample of leaf detritus used here do not reflect actual emissions as accurately as they could. This could be due to variations in leaf wax $n$-alkane composition with season or with the age of the plant, or to variations in the release rates of detritus with the location and/or height of the plant.

Seasonal variations in plant wax $n$-alkane composition have been noted [e.g., Stránský et al., 1967; Baker, 1982], but this alone would not be sufficient to explain the differences observed; while the leaf detritus sample was collected in the late fall, differences between modeled and observed $n$-alkane patterns occur at all locations and months of the year (see Figure 4). Other measurements [Herbin and Robins, 1969; Baker, 1982] suggest that as a plant gets older, the surface wax composition shifts toward higher carbon numbered $n$-alkanes. Since each species of leaf was collected from one or a few representative plants, Figure 4 then would imply that older leaves were overrepresented in our composite sample. However, the only plant species collected that composed a sizeable portion of the composited sample were grasses and a few of the natural species of vegetation. Given the limited growing season of grasses, it seems unlikely that the ages of the two grass samples collected were unrepresentative. Furthermore, the natural species of vegetation were collected in settings that closely mimicked natural growing conditions; thus it seems unlikely that age-dependent sample biases are significant.

Wind is expected to be an important mechanism for dislodging the plant waxes. Given that natural plus cultivated grasses composed almost one third of the composited mass and that they grow close to ground level, where winds are less vigorous, it is possible that plant waxes from grasses were overrepresented in the vegetative detritus samples generated when compared to wind-driven releases from outdoor plants. Some published measurements suggest that the waxes from monocotyledons (such as grasses) tend to have relatively higher amounts of the $\mathrm{C}_{31}$ and $\mathrm{C}_{33} n$-alkanes than dicotyledonous plants [Eglinton et al., 1962; Nishimoto, 1974; Dove and Mayes, 1991], so this may be a possible explanation for the remaining differences between model predictions and ambient measurements.

Second, the possibility that other inventoried sources used in the model have inaccuracies in their odd carbon numbered $n$-alkane contributions should be examined. Over half of the $\mathrm{C}_{31}$ and $\mathrm{C}_{33}$-alkane ambient concentrations predicted to arise from inventoried anthropogenic sources in Los Angeles (see Figure 2) originate from cigarette smoke emissions [Rogge et al., this issue]. Since the composition used here for emissions from cigarette smoke has been determined to be consistent with measurements reported by other researchers [Rogge et al., 1994], this is not considered a likely explanation.

Third, it is possible that other vegetation-derived sources besides surface leaf detritus are contributing to the observed ambient $n$-alkane profiles. Waxes from plant parts such as stems, seeds, and pollen have $n$-alkane profiles that can differ significantly from that of the leaves. For some plant species, the nonleaf $n$-alkane distributions shift toward lower carbon numbers [e.g., Eglinton and Hamilton, 1967; Stránský 

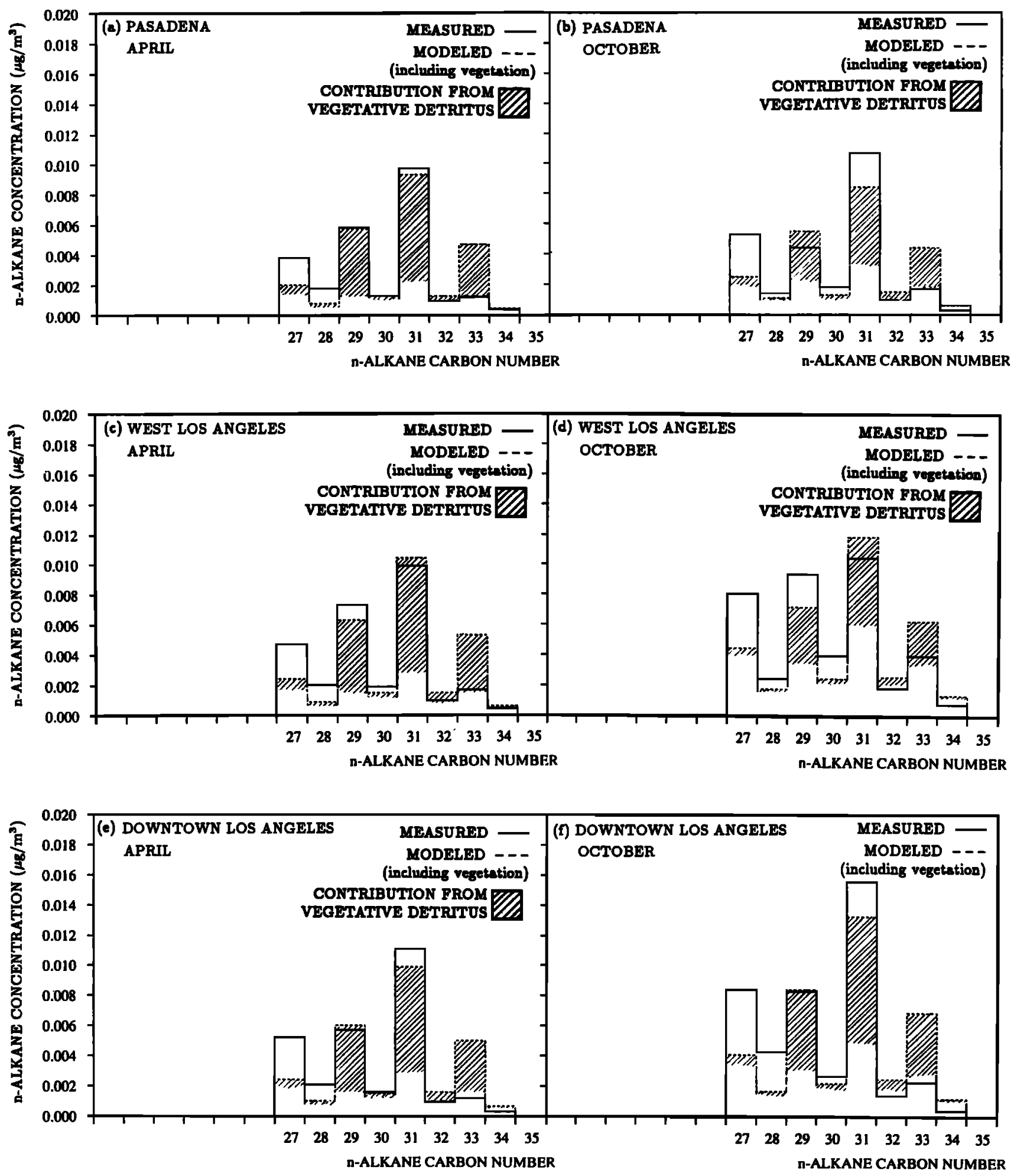

Figure 4. Revised model predictions of ambient $n$-alkane concentrations, including upperbound estimates of the contribution from urban vegetative detritus: (a) Pasadena in April; (b) Pasadena in October; (c) west Los Angeles in April; (d) west Los Angeles in October; (e) downtown Los Angeles in April; and (f) downtown Los Angeles in October.

and Streibl, 1969], while for other species either no trend or the opposite shift has been reported [e.g., Stránský et al., 1967; Herbin and Robins, 1969]. Pollen is particularly noteworthy as a possible source of fine airborne vegetative detritus: utilizing immunoassays, it has been demonstrated that ragweed pollen allergen exists on submicron-sized particles [Habenicht et al., 1984].

A final possibility is that part of the vegetationderived signature in the Los Angeles atmosphere is 
due to another uninventoried anthropogenic source: namely, cooking oils. The significant amount of ambient organic aerosol originating from meat cooking [Hildemann et al., 1991; Rogge et al., 1991] lends credence to the idea that volatilization of oils during frying activities could also contribute to urban organic aerosols.

The $n$-alkane profiles of some of the seed oils most commonly purchased by consumers [McGill et al., 1993] exhibit the pronounced odd-to-even carbon number predominance typical of most plants. While the relative magnitude of the various odd carbon numbered $n$-alkanes differs substantially between different oils, all the consumer seed oils tested contained relatively more $\mathrm{C}_{27}$ and relatively less $\mathrm{C}_{33} n$-alkanes than the vegetative detritus sample. However, since no measurements of speciated emissions from the use of cooking oils have been reported in the literature, utilization of $n$-alkane fingerprints to deduce their magnitude as an emission source is not currently possible.

\section{Examination of Seasonal Trends}

One alternate approach to further evaluating the possible importance of cooking oils versus natural plant emissions as a source of organic aerosol is to examine seasonal trends. While cooking activities would be expected to be a relatively constant emission source throughout the year, natural aerosol emissions from vegetation might be expected to show variation with season.

In Los Angeles, ventilation of the basin varies with season because of changes in wind intensity, wind direction, and inversion base height. To examine the variation in the strength of an emission source with time of the year, these meteorological variations must be removed. Elemental carbon has been used to factor out such meteorological influences in the Los Angeles basin, because it is emitted from well-dispersed sources (motor vehicles) at a nearly constant rate throughout the year and is nonreactive [Cass et al., 1982; Gray et al., 1986; Mazurek et al., 1989; Hildemann et al., 1994]. Any seasonal variations that remain after normalizing the ambient concentrations of a nonreactive species by the coexisting elemental carbon concentrations can be attributed to variations in the strength of the source emissions.

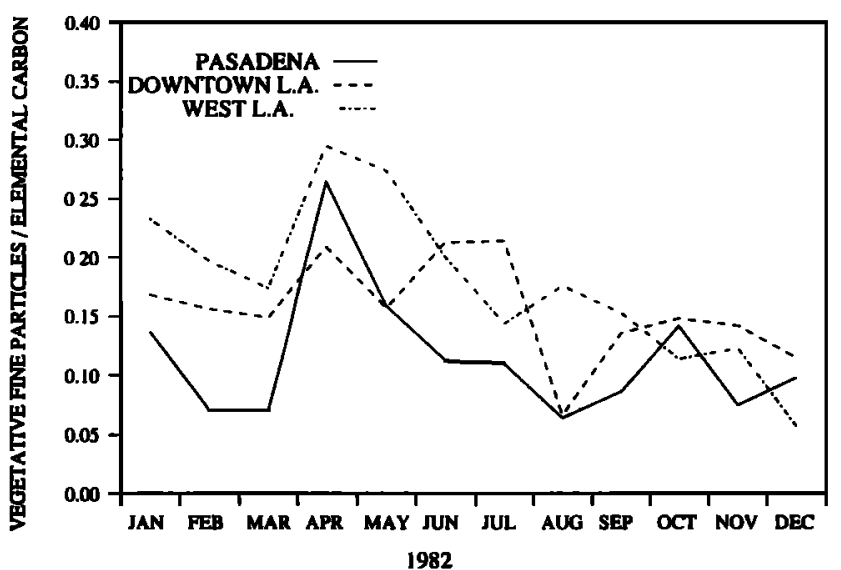

Figure 5. Dilution-normalized monthly average ambient concentrations of vegetation-derived fine aerosol, showing seasonal variations in the source emission strength for three sites in the Los Angeles basin.
When the upperbound predictions of fine ambient aerosol originating from vegetative detritus (from Figure 3) are normalized by concurrently measured elemental carbon concentrations reported by Gray et al. [1986], the seasonal emission strength profiles shown in Figure 5 are obtained. Pasadena shows a strong seasonal peak in likely emissions from vegetation in April and May, while west Los Angeles also appears to show a relative maximum over those same two months. Similar seasonal variations have been observed for various species of pollen in southern California [Ellis and Gallup, 1989], so some of the fine vegetative detritus could originate from disintegrating pollen. The fact that this late spring peak is not clearly evident in the downtown Los Angeles data might then be attributed to the paucity of vegetation in the downtown area; however, other hypotheses for these regional differences cannot be ruled out.

\section{Conclusions}

The relative abundance of $n$-alkanes between $\mathrm{C}_{27}$ and $\mathrm{C}_{34}$ in the emissions from urban anthropogenic sources has been utilized in conjunction with a mathematical model to calculate an upperbound estimate of the amount of ambient aerosol in the Los Angeles basin that could originate from urban vegetation. At most, $0.2-1.0 \mu \mathrm{g} \mathrm{m}^{-3}$ of the ambient fine particulate matter could originate as vegetative detritus dislodged from the surfaces of plant leaves. This upperbound concentration would correspond to approximately $1-3 \%$ of the total fine ambient particulate matter present in the Los Angeles atmosphere.

However, the odd carbon number predominance observed for the higher molecular weight $n$-alkanes in the urban atmosphere also could originate in part from the use of cooking oils. Seasonal trends were examined in an effort to distinguish between natural sources whose emissions may follow seasonal patterns and anthropogenic emission sources, such as cooking oil use, whose emission rates would be expected to be roughly constant throughout the year. At two of the three sites investigated, a distinct seasonal variation in the source emissions of vegetation-derived particulate matter is observed, with peaks during the spring growing season (April to May), suggesting that at least a significant part of the vegetation-derived aerosol emissions is indeed attributable to natural vegetation. It is hypothesized that in addition to surface leaf detritus, plant-derived materials such as pollen may contribute to the springtime peak observed.

\section{References}

Baker, E.A., Chemistry and morphology of plant epicuticular waxes, in The Plant Cuticle, edited by D.F. Cutler, K.L. Alvin, and C.E. Price, pp. 139-165, Academic, San Diego, Calif., 1982.

Cass, G.R., Methods for sulfate air quality management with applications to Los Angeles, Ph.D. thesis, Calif. Inst. of Technol., Pasadena, 1977.

Cass, G.R., Sulfate air quality control strategy design, Atmos. Environ., 15, 1227-1249, 1981.

Cass, G.R., P.M. Boone, and E.S. Macias, Emissions and air quality relationships for atmospheric carbon particles in Los Angeles, in Particulate Carbon: Atmospheric Life Cycle, edited by G.T. Wolff and R.L. Klimisch, pp. 207-240, Plenum, New York, 1982.

Cox, R.E., M.A. Mazurek, and B.R.T. Simoneit, Lipids in Harmattan aerosols of Nigeria, Nature, 296, 848-849, 1982. 
Doskey, P.V., and A.W. Andren, Particulate- and vaporphase n-alkanes in the northern Wisconsin atmosphere, Atmos. Environ., 20, 1735-1744, 1986.

Dove, H., and R.W. Mayes, The use of plant wax alkanes as marker substances in studies of the nutrition of herbivores: A review, Aust. J. Agric. Res., 42, 913-952, 1991.

Eglinton, G., and R.J. Hamilton, The distribution of alkanes, in Chemical Plant Taxonomy, edited by T. Swain, pp. 187-217, Academic, San Diego, Calif., 1963.

Eglinton, G., and R.J. Hamilton, Leaf epicuticular waxes, Science, 156, 1322-1335, 1967.

Eglinton, G., R.J. Hamilton, and M. Martin-Smith, The alkane constituents of some New Zealand plants and their possible taxonomic implications, Phytochemistry, 1, 137-145, 1962.

Ellis, M.H., and J. Gallup, Aeroallergens of southern California, Immunol. Allergy Clin. North Am., 9, 365-380, 1989.

Gagosian, R.N., O.C. Zafiriou, E.T. Peltzer, and J.B. Alford, Lipids in aerosols from the tropical North Pacific: Temporal variability, J. Geophys. Res., 87, 11133-11144, 1982.

Gray, H.A., Control of atmospheric fine primary carbon particle concentrations, EQL Rep. 23, Environ. Qual. Lab. Calif. Inst. of Technol., Pasadena, 1986.

Gray, H.A., G.R. Cass, J.J. Huntzicker, E.K. Heyerdahl, and J.A. Rau, Characteristics of atmospheric organic and elemental carbon particle concentrations in Los Angeles, Environ. Sci. Technol., 20, 580-589, 1986.

Habenicht, H.A., H.A. Burge, M.L. Muilenberg, and W.R. Solomon, Allergen carriage by atmospheric aerosol, II, Ragweed-pollen determinants in submicronic atmospheric fractions, J. Allergy Clin. Immunol., 74, 64-67, 1984.

Herbin, G.A., and P.A. Robins, Patterns of variation and development in leaf wax alkanes, Phytochemistry, 8, 1985-1998, 1969.

Hildemann, L.M., G.R. Markowski, and G.R. Cass, Chemical composition of emissions from urban sources of fine organic aerosol, Environ. Sci. Technol., 25, 744-759, 1991.

Hildemann, L.M., G.R. Cass, M.A. Mazurek, and B.R.T Simoneit, Mathematical modeling of urban organic aerosol: Properties measured by high-resolution gas chromatography, Environ. Sci. Technol., 27, 2045-2055, 1993.

Hildemann, L.M., M.A. Mazurek, G.R. Cass, and B.R.T. Simoneit, Seasonal trends in Los Angeles ambient organic aerosol observed by high-resolution gas chromatography, Aerosol Sci. Technol., 20, 303-317, 1994.

Kolattukudy, P.E., Cutin, suberin, and waxes, in The Biochemistry of Plants, vol. 4, edited by P.K. Stumpf, pp. 571-645, Academic, San Diego, Calif., 1980.

Mazurek, M.A., and B.R.T. Simoneit, Characterization of biogenic and petroleum-derived organic matter in aerosols over remote, rural and urban areas, in Identification and Analysis of Organic Pollutants in Air, edited by L.H. Keith, pp. 353-370, Butterworth-Heinemann, Stoneham, Mass. 1984.

Mazurek, M.A., B.R.T. Simoneit, G.R. Cass, and H.A. Gray, Quantitative high-resolution gas chromatography and highresolution gas chromatography/mass spectromętry analyses of carbonaceous fine aerosol particles, Int. J. Environ. Anal. Chem., 29, 119-139, 1987.

Mazurek, M.A., G.R. Cass, and B.R.T. Simoneit, Interpretation of high-resolution gas chromatography and highresolution gas chromatography/mass spectrometry data acquired from atmospheric organic aerosol samples, Aerosol Sci. Technol., 10, 408-420, 1989.

Mazurek, M.A., G.R. Cass, and B.R.T. Simoneit, Biological input to visibility-reducing aerosol particles in the remote arid southwestern United States, Environ. Sci. Technol., 25, 684-694, 1991.

Mazurek, M.A., L.M. Hildemann, G.R. Cass, B.R.T. Simoneit, and W.F. Rogge, Methods of analysis for complex organic aerosol mixtures from urban emission sources of particulate carbon, in Sampling and Analysis of Airborne Pollutants, edited by E.D. Winegar and L.H. Keith, pp. 178-190, Lewis, Boca Raton, Fla., 1993.
McGill, A.S., C.F. Moffat, P.R. Mackie, and P. Cruickshank The composition and concentration of $n$-alkanes in retail samples of edible oils, J. Sci. Food Agric., 61, 357-362, 1993.

Miller, P.R., and A.M. Winer, Composition and dominance in Los Angeles basin urban vegetation, Urban Ecol, , 8, 29-54, 1984.

Nishimoto, S., A chemotaxonomic study of $n$-alkanes in leaf surface waxes of terrestrial plants, J. Sci. Hiroshima Univ., Ser. A, Phys. Chem., 38, 151-158, 1974.

Rogge, W.F., L.M. Hildemann, M.A. Mazurek, G.R. Cass, and B.R.T. Simoneit, Sources of fine organic aerosol, 1, Charbroilers and meat cooking operations, Environ. Sci. Technol., 25, 1112-1125, 1991.

Rogge, W.F., L.M. Hildemann, M.A. Mazurek, G.R. Cass, and B.R.T. Simoneit, Sources of fine organic aerosol, 3, Road dust, tire debris, and organometallic brake lining dust - Roads as sources and sinks, Environ. Sci. Technol., 27, 1892-1904, 1993a.

Rogge, W.F., L.M. Hildemann, M.A. Mazurek, G.R. Cass, and B.R.T. Simoneit, Sources of fine organic aerosol, 4, Particles shed from leaf surfaces of urban plants, Environ. Sci. Technol., 27, 2700-2711, 1993b.

Rogge, W.F., M.A. Mazurek, L.M. Hildemann, G.R. Cass, and B.R.T. Simoneit, Quantification of urban organic aerosols at a molecular level: Identification, abundance and seasonal variation, Atmos. Environ. Part A, 27, 1309-1330, 1993c.

Rogge, W.F., L.M. Hildemann, M.A. Mazurek, G.R. Cass, and B.R.T. Simoneit, Sources of fine organic aerosol, 6 , Cigarette smoke in the urban atmosphere, Environ. Sci. Technol., 28, 1375-1388, 1994.

Rogge, W.F., L.M. Hildemann, M.A. Mazurek, G.R. Cass, and B.R.T. Simoneit, Mathematical modeling of atmospheric fine-particle-associated primary organic compound concentrations, J. Geophys. Res, this issue.

Sicre, M.A., J.C. Marty, and A. Saliot, n-Alkanes, fatty acid esters, and fatty acid salts in size-fractionated aerosols collected over the Mediterranean Sea, J. Geophys. Res., 95, 3649-3657, 1990.

Simoneit, B.R.T., Biogenic lipids in eolian particulates collected over the ocean, in Proceedings Carbonaceous Particles in the Atmosphere, Rep. LBL-9097, edited by T. Novakov, pp. 233-244, Natl. Sci. Found., Washington, D.C., 1979 .

Simoneit, B.R.T., Characterization of organic constituents in aerosols in relation to their origin and transport: A review, Int. J. Environ. Anal. Chem., 23, 207-237, 1986.

Simoneit, B.R.T., Organic matter of the troposphere, $\mathrm{V}$, Application of molecular marker analysis to biogenic emissions into the troposphere for source reconciliations, J. Atmos. Chem., 8, 251-275, 1989.

Simoneit, B.R.T., and M.A. Mazurek, Air pollution: The organic components, Crit. Rev. Environ. Control, 11, 219-276, 1981.

Simoneit, B.R.T., and M.A. Mazurek, Organic matter of the troposphere, II, Natural background of biogenic lipid matter in aerosols over the rural western United States, Atmos. Environ., 16, 2139-2159, 1982.

Simoneit, B.R.T., R.E. Cox, and L.J. Standley, Organic matter in the troposphere, IV, Lipids in Harmattan aerosols of Nigeria, Atmos. Environ., 22, 983-1004, 1988.

Simoneit, B.R.T., J.N. Cardoso, and N. Robinson, An assessment of the origin and composition of higher molecular weight organic matter in aerosols over Amazonia, Chemosphere, 21, 1285-1301, 1990.

Simoneit, B.R.T., P.T. Crisp, M.A. Mazurek, and L.J. Standley, Composition of extractable organic matter of aerosols from the Blue Mountains and southeast coast of Australia, Environ. Int., 17, 405-419, 1991a.

Simoneit, B.R.T., G. Sheng, X. Chen, J. Fu, J. Zhang, and Y. $\mathrm{Xu}$, Molecular marker study of extractable organic matter in aerosols from urban areas of China, Atmos. Environ. Part $A, 25,2111-2129,1991 b$.

Stránský, K., and M. Streibl, On natural waxes, XII, Composition of hydrocarbons in morphologically different 
plant parts, Collect. Czech. Chem. Commun., 34, 103-117, 1969.

Stránský, K., M. Streibl, and V. Heront, On natural waxes, VI, Distribution of wax hydrocarbons in plants at different evolutionary levels, Collect. Czech. Chem. Commun., 32, 3213-3220, 1967.

Wils, E.R.J., A.G. Hulst, and J.C. Hartog, The occurrence of plant wax constituents in airborne particulate matter in an urbanized area, Chemosphere, 11, 1087-1096, 1982.

Winer, A.M., D.R. Fitz, and P.R. Miller, Investigation of the role of natural hydrocarbons in photochemical smog formation in California, report, Statewide Air Pollut. Res. Cent., Univ. of Calif., Riverside, 1983.

G.R. Cass, Department of Environmental Engineering Science, M/S 138-78, California Institute of Technology, Pasadena, CA 91125.
L.M. Hildemann (corresponding author), Environmental Engineering and Science Program, Department of Civil Engineering, Stanford University, Stanford, CA 94305-4020. (e-mail: hildemann@smog.stanford.edu)

M.A. Mazurek, Institute of Marine and Coastal Sciences, Rutgers University, New Brunswick, NJ 08903-0231. (e-mail: mazurek@ahab.rutgers.edu)

W.F. Rogge, Department of Civil and Environmental Engineering, Florida International University, Miami, FL 33199. (e-mail: rogge@eng.fiu.edu)

B.R.T. Simoneit, College of Oceanic and Atmospheric Sciences, Oregon State University, Corvallis, OR 97331.

(Received October 25, 1994; revised April 24, 1995; accepted June 14, 1995.) 